\title{
ОСОБЛИВОСТІ ВИКОРИСТАННЯ СПЕЦІАЛЬНИХ ПСИХОЛОГЧНИХ ЗНАНЬ В АДМІНІСТРАТИВНИХ ПРОВАДЖЕННЯХ
}

\begin{abstract}
ЧЕРНОВСЬКИЙ Олексій Костянтинович - доктор юридичних наук, суддя апеляційного суду Чернівецької області у відставці заслужений юрист України ФЕДІНА Аліна Василівна - кандидат юридичних наук, суддя Першотравневого районного суду м. Чернівці
\end{abstract}

DOI:10.32782/EP.2020.2.4

\begin{abstract}
Сучасне адміністративне правосуддя спрямоване на справедливий, неупереджений та своєчасний розгляд $i$ вирішення адміністративних справ з метою ефективного захисту порушених невизнаних або оспорюваних прав, свобод чи інтересів бізичної особи, прав та інтересів юридичних осіб, інтересів держави. Застосування спеціальних психологічних знань або ж «спеціальних знанъ» в окремих категоріях адміністративних проваджень у вигляді залучення консультанта - психолога та/або призначення судово-психологічної експертизи буде в илілому ебективно сприяти вирішенню завдань адміністративного судочинства окреслених вище та закріплених в ст.2 Кодексу адміністративного судочинства України.

Ключові слова: спечіальні психологічні знання, експертиза, спеціаліст, адміністративне провадження, примирення.
\end{abstract}

Напрямок розвитку сучасної України шляхом побудови демократичної держави характеризується трансформацією всіх сфер життєдіяльності суспільства, включаючи й реформування процесуального законодавства. На даному етапі суспільного розвитку формується принципово нове ставлення до судової гілки влади, як до однієї з важливих державних інституцій, яка покликана забезпечити дієвий захист законних прав та інтересів громадян України, в тому числі і у сфері публічно-правових відносин від порушень з боку суб'єктів владних повноважень.
Необхідність гуманізації і, відповідно, психологізації юрисдикційної діяльності сьогодні не викликає сумнівів ні в керівництва держави, ні в самих працівників, ні в громадян, які є об'єктом юрисдикційного процесу. Тому зростаючі вимоги держави і суспільства до ефективності судової влади повинні супроводжуватися проведенням наукових практичних досліджень, присвячених визначенню теоретико-методологічних засад впровадження в процесуальне законодавство спеціальних психологічних знань, їх можливостей та перспектив використання.

Слушною в науці $є$ думка про те, що слідчий, прокурор, адвокат, суддя в межах своїх повноважень можуть самостійно застосовувати будь-які спеціальні знання, за винятком тих випадків, коли вони не володіють певними знаннями або вважають за необхідне залучити іншого більш кваліфікованого спеціаліста чи з міркувань технологічного процесу використання процесуальних дій, а також у випадках, коли законом передбачено залучення конкретних спеціалістів (лікарів, перекладачів, психологів тощо) чи проведення судової експертизи.

На думку Б. В. Романюка, спеціальні знання - це сукупність науково обгрунтованих відомостей окремого (спеціального) виду, якими володіють особи (спеціалісти) у межах будь-якої професії в різних галузях науки, техніки, мистецтва та ремесла і які використовуються ними для успішно- 
го вирішення завдань судочинства. У цьому аспекті дається й визначення спеціаліста у широкому розумінні як будь-якого суб'єкта, котрий володіє спеціальними знаннями, водночас констатується, що спеціалістом - учасником провадження $є$ лише та обізнана особа, яка за вимогою слідчого, прокурора або суду бере участь у проведенні слідчих чи судових дій [1, с 9].

Спеціальні знання, з огляду М. В. Ревака, складають, як правило, цілісну систему наукових знань 3 їі практичною спрямованістю, до складу якої входить порядок і спосіб дослідження, певні спеціальні терміни, зрозумілі тільки для поінформованих у цій галузі осіб, а не окремі уривчасті дані, що мають загальновживане, загальнозастосовне значення [2, с 13]. Вчений П. Карпечкін під спеціальними знаннями розуміє результат отримання інформації в якому-небудь визначеному виді справ, діяльності людини, що становлять собою визначені відомості на певному етапі, а так як науково-технічний прогрес перебуває у постійному розвитку, то знання можуть втрачати своє актуальне значення, бути застарілими [3, с 117].

Натомість В. В. Семенов визначає спеціальні знання як «неодноразово апробовані наукові знання, практичні вміння та навички, які сформувалися під час отримання загальної та професійної освіти, досвіду роботи за спеціальністю і які можна використати відповідно до процедурних правил процесуального закону для вирішення його завдань» [4, с 8, 9]. УченимВ. М. Шерстюком наведені загальні та особливі ознаки спеціальних знань у процесуальному сенсі. До загальних віднесені знання, якими володіє обмежена кількість фахівців, такі знання не $є$ загальновідомими чи загальнодоступними, а особливі, на думку автора, не охоплюють професійних знань слідчого, прокурора, захисника, судді, тобто професійні знання щодо норм матеріального та процесуального права України [5, с 20].

Учений I. В. Пиріг виділяе досить слушні критерії, що варто використовувати при визначені поняття «спеціальних знань», а саме: а) спеціальні знання не є професійними для слідчого, працівників органів дізнання, прокурора, судді;б) спеціальні знання повинні базуватись на досягненнях науки і не можуть бути загальновідомими; в) за способом отримання спеціальні знання набуваються шляхом теоретичного засвоєння певної інформації або періодичними практичними заняттями окремим видом роботи: г) загальна мета використання спеціальних знань сприяння вирішенню завдань кримінального судочинства [6, с 7].

Ми погоджуємося 3 думкою С. С Чернявського, який зазначив, що ступінь врегулювання процесуальним законом конкретної форми участі фахівця є досить умовним, оскільки для процесу встановлення істини у справі доказом можуть бути визнані будь-які фактичні дані [7, с 121].

Використання спеціальних психологічних знань в адміністративному провадженні належать до загального поняття «спеціальні знання», оскільки в Кодексі адміністративного судочинства України (далі КАС України) посилання на використання спеціальних психологічних знань відсутне. Разом з тим, ми проаналізували окремі положення щодо застосування спеціальних знань у КАС України, процесуальні особливості використання яких регулюють і застосування спеціальних психологічних знань.

Так, стаття 68 КАС України регулює особливості застосування спеціальних знань, необхідних для з'ясування відповідних обставин справи, статтею 70 КАС України передбачено особливості надання консультативної допомоги, статтею 101 КАС України передбачені вимоги до висновку експерта, тобто процесуальні особливості проведення експертом досліджень, а також статтями 102-111 КАС України передбачено особливості призначення судом експертизи, тобто опис сукупності вимог, необхідних для призначення експертизи та чинників, які слід врахувати [8].

Незважаючи на існування чітких норм адміністративного процесуального законодавства в кожному конкретному адміністративному провадженні, виникає безліч 


\section{Адміністративне право}

питань 3 приводу визначення необхідності та потреби в спеціальних психологічних знаннях, адже загальний предмет використання спеціальних психологічних знань в адміністративному провадженні має однозначно враховувати: експертну (психологічну) значимість результатів психологічного дослідження; потенційну доказову значимість результатів такого дослідження.

3 огляду на вищевикладене можна дійти висновку, що використання спеціальних психологічних знань в адміністративному провадженні часто залежить від обгрунтованого сумніву, який грунтується на доказах, які допомагають встановленню наявності або відсутності певних публічно-правових обставин на засадах змагального судового процесу. Загалом використання спеціальних психологічних знань у адміністративному провадженні на вказаних підставах грунтується на інформації об'єктивного характеру щодо відповідних відомостей про певний емоційний, психічний та психологічний стан, особливості психічних процесів досліджуваних осіб.

Використання спеціальних психологічних знань є відмінними від різновиду спеціальних знань - психіатричних за такими критеріями:

- спеціальні психіатричні знання допомагають виявити здатність: трактувати обставини, що мають значення для справи; адекватно запам'ятовувати і відтворювати інформацію; повною мірою усвідомлювати фактичний зміст своїх дій; здійснювати свідоме, вольове управління своїми діями;

- спеціальні психологічні знання допомагають виявити наявність: приховування або перекручування обставин, що мають значення для справи; викривлення фактів замість реальних відомостей, свідому дезінформацію; впливу станів зміненої свідомості (стресу, фрустрації, афекту тощо) на сприйняття досліджуваних подій, щирої помилки або свідомої омани [9, с 58].

Психологічна експертиза є однією 3 форм застосування спеціальних психологічних знань в адміністративному судочинстві, яка допомагає суду у вирішенні питань психологічного змісту. На сьогодні психологічна експертиза має велике значення при встановленні істини в адміністративному судочинстві, оскільки питання, які необхідно вирішити в ході судового процесу, пов'язані безпосередньо 3 особами, які беруть участь у справі. Об'єктом судово-психологічної експертизи є психічна діяльність здорової людини.

У статті 1 Закону України «Про судову експертизу» визначено поняття судової експертизи - дослідження на основі спеціальних знань у галузі науки, техніки, мистецтва, ремесла тощо об'єктів, явищ i процесів з метою надання висновку 3 питань, що є або будуть предметом судового розгляду.

Кодекс адміністративного судочинства України визначає два варіанти проведення експертизи - за ухвалою суду та на замовлення учасників процесу.

У першому випадку суд зупиняє провадження у справі на час проведення експертизи, а в другому учасник справи може підготувати висновок експерта як під час судового розгляду, так і до подання позову до суду.

Суд за клопотанням учасника справи або з власної ініціативи призначає експертизу у справі за сукупності умов, зазначених у статті 102 КАС України, а саме: для з'ясування обставин, що мають значення для справи, необхідні спеціальні знання у сфері іншій, ніж право, без яких встановити відповідні обставини неможливо та якщо жодною стороною не наданий висновок експерта 3 цих самих питань або висновки, надані сторонами, викликають обгрунтовані сумніви щодо їх неправильності. Учасники справи мають право запропонувати суду ряд питань, роз'яснення яких, на їх думку, потребує висновку експерта. Остаточні питання, 3 яких має бути проведена експертиза, визначаються судом, проте питання, які ставляться експерту, i його висновок $з$ них не можуть виходити за межі спеціальних знань експерта.

За результатами вирішення клопотання суд виносить ухвалу, в якій зазначає підстави проведення експертизи, питання, 3 яких експерт має надати суду висновок, 
особу (осіб), якій (яким) доручено проведення експертизи, перелік матеріалів, що надаються для дослідження, та інші дані, які мають значення для проведення експертизи. При призначенні експертизи судом експерт або експертна установа обирається сторонами за взаємною згодою, а якщо такої згоди не досягнуто у встановлений судом строк, експерта чи експертну установу визначає суд. 3 урахуванням обставин справи суд може визначити експерта чи експертну установу самостійно.

Якщо в одному документі про призначення експертизи є питання, що стосуються різних видів експертиз, не пов'язаних між собою, керівник установи визначає, які питання підлягають вирішенню у відповідному підрозділі та послідовність їх виконання.

Щодо процедури залучення експерта до судового процесу, окрім призначення експертизи судом, передбачена можливість проведення експертизи на замовлення учасників справи. Учасник справи, який замовляє експертизу поза межами судового засідання, на власний розсуд обирає відповідного експерта або експертну установу, що буде проводити експертне дослідження та самостійно ставить питання, які потребують роз'яснення експертом. Якщо позасудове експертне дослідження пов'язане 3 повним або частковим знищенням об'єкта експертизи або зміною його властивостей, експерт має повідомити про це особу, яка до нього звернулася.

Висновком експерта слід вважати наданий експертом у письмовій формі докладний опис проведених під час експертизи досліджень, зроблені у їх результаті висновки щодо досліджених об'єктів, явищ чи процесів та обгрунтовані відповіді на поставлені питання, що дають інформацію про обставини у справі.

Варто зазначити, що висновок експерта, складений за ухвалою суду, та висновок експерта, підготовлений на замовлення учасника справи, повинен містити запис, де вказано, що експерт обізнаний про кримінальну відповідальність за завідомо неправдивий висновок.
Експерт, який склав висновок за зверненням учасника справи, має такі самі права і обов'язки, що й експерт, який здійснює експертизу на підставі ухвали суду. Висновок експерта, отриманий у різному порядку, матиме однаковий процесуальний статус доказу, поданого до суду. Якщо інший учасник справи матиме підстави для відводу експерта, який підготував висновок на замовлення іншої особи, такий висновок судом до розгляду не приймається, якщо суд визнає наявність таких підстав.

Висновок експерта для суду не має заздалегідь встановленої сили і оцінюється судом разом із іншими доказами за правилами, встановленими статтею 90 КАС України. Aле у будь-кому випадку незгода суду з висновком експерта повинна бути вмотивована у судовому рішенні.

Отже, висновок експерта - це засіб доказування, який формується експертом у результаті проведеного дослідження, заснованого на застосуванні спеціальних знань, на замовлення учасника справи або на підставі ухвали суду про призначення експертизи і складається у формі та в порядку, передбаченому КАС України, ЗУ «Про судову експертизу», Інструкцією про призначення та проведення судових експертиз та експертних досліджень.

Щодо консультації, як однієї з форм використання знань спеціаліста, то, на нашу думку, вона повинна застосовуватися сторонами адміністративного провадження та судом на всіх етапах провадження.--У цьому контексті необхідно звернути увагу на зміст статей 70, 81, 82, 211, 217, 222 КАС України. Так, статтею 70 КАС України передбачено, що спеціалістом є особа, яка володіє спеціальними знаннями та навичками, необхідними для застосування технічних засобів, і призначена судом для надання консультацій та технічної допомоги під час вчинення процесуальних дій, пов'язаних із застосуванням таких технічних засобів (фотографування, складання схем, планів, креслень, відбору зразків для проведення експертизи тощо). Допомога та консультації спеціаліста не замінюють висновок експерта. Спеціаліст 


\section{Адміністративне право}

зобов'язаний з'явитися до суду за його викликом, відповідати на поставлені судом питання, надавати консультації та роз'яснення, у разі потреби надавати суду іншу технічну допомогу. За відсутності заперечень учасників справи спеціаліст може брати участь у судовому засіданні в режимі відеоконференції. Спеціаліст має право знати мету свого виклику до суду, відмовитися від участі у судовому процесі, якщо він не володіє відповідними знаннями та навичками, звертати увагу суду на характерні обставини чи особливості доказів, а також право на оплату виконаної роботи та на компенсацію витрат, пов'язаних із викликом до суду. Статтями 81, 82 КАС України передбачено, що у разі необхідності, в тому числі за клопотанням учасника справи, для участі в огляді доказів за їх місцем знаходженням та тих доказів, що швидко псуються, можуть бути залучені свідки, перекладачі, експерти спеціалісти, а також здійснено фотографування, звукоі відеозапис. Суд може призначити експертизу для встановлення та фіксування змісту веб-сайту (сторінки), інших місць збереження даних у мережі Інтернет за умови, якщо це потребує спеціальних знань і не може бути здійснено судом самостійно або із залученням спеціаліста.

Статтями 21 1, 217, 222 КАС України передбачено, що суд під час розгляду справи повинен безпосередньо дослідити докази у справі: ознайомитися 3 письмовими та електронними доказами, висновками експертів, поясненнями учасників справи, викладеними в заявах по суті справи, показаннями свідків, оглянути речові докази. Докази, що не були предметом дослідження в судовому засіданні, не можуть бути покладені судом в основу ухваленого судового рішення. Речові, письмові та електронні докази оглядаються у судовому засіданні, за винятком випадків, визначених цим Кодексом, і пред'являються учасникам справи за їхнім клопотанням, а в разі необхідності - також свідкам, експертам, спеціалістам. Письмові докази, у тому числі протоколи їх огляду, складені за судовим дорученням або в порядку забезпечення доказів, за клопотанням учасника справи пред'являються йому для ознайомлення, а в разі необхідності - також свідкам, експертам,спеціалістам чи перекладачам, або оголошуються в судовому засіданні. Учасники справи можуть ставити питання свідкам, експертам, спеціалістам з приводу письмових доказів. Під час дослідження доказів суд може скористатися технічною допомогою, усними консультаціями спеціаліста. Спеціалісту можуть бути поставлені питання щодо суті наданої технічної допомоги, усних консультацій. Першими ставлять питання особа, за клопотанням якої залучено спеціаліста, та її представник, а потім інші учасники справи. Якщо спеціаліста залучено за клопотанням обох сторін, першими ставлять питання спеціалісту позивач і його представник. Головуючий у судовому засіданні та інші судді можуть ставити спеціалістові питання в будь-який час дослідження доказів. До того ж консультацію та роз'яснення спеціаліста варто, як пишуть професор В. Марчак [10, с 10] та академік М. Костицький [11, с. 159], розцінювати поряд 3 іншими процесуальними доказами.

Досить слушною є думка професораH. С. Карпова, який вважає, «що при наявності джерела даних і відомостях про нього не потрібне його додаткове опрацювання, оскільки суд - єдиний орган, що вирішує справу по суті - може в разі потреби звернутися до будь-якого джерела даних для перевірки їх вірогідності» [12, с 214$].$ Виходячи 3 означеного, письмовий висновок спеціаліста має бути віднесений до окремого виду джерела доказів, що, звичайно, послужить повному, всебічному та об’єктивному здійсненню судового провадження.

Таким чином, вміле використання учасниками адміністративного провадження спеціальних знань у юрисдикційному процесі зможе оптимізувати встановлення важливих обставин справи та з'ясування істинної мотивації предмету спору сторін у судовій справі. Як свідчить судова практика, сторони адміністративного провадження та їх представники, адвокати не часто виступають ініціаторами залучення спеціаліста до юрисдикційного процесу, 
зокрема адміністративного, через недостатню обізнаність у вузько прикладних питаннях, які потрібно було б з'ясувати в межах того чи іншого заявленого предмету спору сторін.

При розгляді питання використання спеціальних психологічних знань в адміністративних провадженнях особливе місце займає інститут примирення (медіації) сторін у процесуальному судочинстві та роль у цьому суду, оскільки сам по собі адміністративний процес, як і інші процеси, такі як цивільний, господарський та кримінальний процеси, $\epsilon$ конфліктними за психологічним змістом. Останнім часом у процесуальному законодавстві України (кримінальному, цивільному, адміністративному, господарському) досить активно запроваджуються норми ювенальної юстиції і відновного правосуддя, які, на нашу думку, передбачають активну роль суду.

Окрема глава 4 КАС України передбачає врегулювання спору за участю судді, відповідно до змісту якої передбачені підстави проведення такого врегулювання (ст. 184 КАС України), порядок призначення (ст. 185 КАС України), порядок проведення (ст. 186 КАС України), строки проведення (ст.. 187 КАС України) та припинення врегулювання спору за участю судді (ст. 188 КАС України). Крім того, статтею 190 КАС України передбачено, що сторони можуть повністю або частково врегулювати спір на підставі взаємних поступок. Примирення сторін може стосуватися лише прав та обов'язків сторін. Сторони можуть примиритися на умовах, які виходять за межі предмета спору, якщо такі умови примирення не порушують прав чи охоронюваних законом інтересів третіх осіб. Умови примирення не можуть суперечити закону або виходити за межі компетенції суб'єкта владних повноважень. За клопотанням сторін суд зупиняе провадження у справі на час, необхідний їм для примирення. Умови примирення сторони викладають у заяві про примирення сторін. Заява про примирення сторін може бути викладена у формі єдиного документа, підписаного сторонами, або у формі окремих документів: заяви однієї сторони про умови примирення та письмової згоди іншої сторони з умовами примирення. До ухвалення судового рішення у зв'язку 3 примиренням сторін суд роз'яснюе сторонам наслідки такого рішення, перевіряє, чи не обмежені представники сторін у праві вчинити відповідні дії. Умови примирення сторін затверджуються ухвалою суду. Затверджуючи умови примирення сторін, суд цією самою ухвалою одночасно закриває провадження у справі. Суд постановляє ухвалу про відмову у затвердженні умов примирення i продовжує судовий розгляд, якщо: 1) умови примирення суперечать закону чи порушують права чи охоронювані законом інтереси інших осіб або є невиконуваними; або 2) одну зі сторін примирення представляє іï законний представник, дії якого суперечать інтересам особи, яку він представляє.

Таким чином, успішно проведена суддею процедура врегулювання спору заощадить місяці, а іноді й роки судових засідань, за результатами яких іноді незадоволеними залишається кожна з сторін. Ефективність такої процедури залежить від надання суддям фахових знань про медіацію, напрацюванням ними їі навичок і навіть опанування психологічними прийомами впливу та в цілому застосування спеціальних психологічних знань. Як відомо, в даний час суди працюють в умовах кадрового дефіциту та надмірного навантаження. У деяких судах інтервали між судовими засіданнями, а також первісні призначення справ до судового розгляду, становлять від двох до шести місяців. Процедура врегулювання спору за участю судді проводиться поза судовим розглядом та не враховується як додаткове навантаження. Відтак, виникають питання з приводу тривалості проведення процедури примирення. Залишення без вирішення вищезазначених питань може призвести до нівелювання значення доволі перспективного процесуального інституту врегулювання спорів за участю судді. На нашу думку, це не є ідеальним процесуальним інститутом, проте якщо він буде вдало імплементований на практиці, це значно зменшить навантаження на суди. 


\section{Адміністративне право}

Крім того, в особі судді сторони отримують представника влади, який на цей період не так жорстко зв'язаний процесуальними нормами. Адже він може професійно працювати над конфліктом, має певний життєвий досвід, мудрість і достатньо розуміється на психологічних аспектах, щоб успішно вирішити конфлікт на початковій стадії звернення до суду. Крім того, суддя затверджує умови мирової угоди. Вбачається, що, запроваджуючи цей інститут, законодавець спирався на багатий іноземний досвід і намагався досягти двох цілей. По-перше, було бажання дати сторонам можливість використовувати багатий суддівський досвід у вирішенні подібних спорів, реально зважити свою позицію, позбавитись від необхідності пошуку третейського судді. По-друге, зміцнити довіру до судової гілки влади в суспільстві.

Таким чином, зважаючи на все вищевикладене, вважаємо, що спеціальні знання включають такі наукові, технічні та практичні знання, які одержані особою в результаті професійного навчання та роботи за певною спеціальністю. Носій цих знань і залучається до юридичної практики в якості спеціаліста або експерта. Такі професіонали, як вбачається із матеріалів судових проваджень, широко використовуються майже у всіх різновидах юрисдикційної діяльності. Крім того, спеціальні психологічні знання в адміністративному провадженні можуть бути реалізовані для проведення психолого-правового аналізу 3 метою підвищення ефективності функціонування адміністративного законодавства в цілому. Також, на нашу думку, запровадження інституту медіації в порядку адміністративного судочинства має відбуватися більш активно.

\section{Література}

1. Романюк Б. В. Сучасні теоретичні та правові проблеми використання спеціальних знань у досудовому слідстві: автореф. дис. на здобуття наук, ступеня канд. юрид. наук : спец. 12.00.09 «Кримінальний процес та криміналістика ; судова експертиза» / Б. В. Романюк. - Київ, 2002. - 22 c.
2. Ревака В. М. Форми використання спеціальних пізнань в досудовому провадженні: автореф. дис. на здобуття наук, ступеня канд. юрид. наук : спец. 12.00.09 «Кримінальний процес та криміналістика ; судова експертиза» /В. М. Ревака. - Харків, 2006. - 21 с.

3. Карпечкін П. Щодо меж спеціальних знань при проведенні судової експертизи у господарському процесі /П. Карпечкін // Вісник прокуратури. 2010. - № 3 (105). - C 114-125.

4. Семенов В. В. Спеціальні знання в розслідуванні злочинів (зміст, організація використання): авторе буття наук, ступеня канд. юрид. наук : спец. 12.00.09 «Кримінальний процес та криміналістика ; судова експертиза» /В. В. Семенов. - Київ, 2006.-20 с.

5. Шерстюк В. М. Організаційно-правові та морально-психологічні засади судово-експертної діяльності : дис. ... канд. юрид. наук: 12.00.09 / Шерстюк Віра Миколаївна. - Харків, 2007. - 199 с.

6. Пиріг I. В. Теорія і практика використання спеціальних знань при розслідуванні розкрадань вантажів на залізничному транспорті: автореф. дис. на здобуття наук, ступеня канд. юрид. наук: спец. 12.00.09 «Кримінальний процес та криміналістика ; судова експертиза» /I. В. Пиріг. - Київ, 2006. - 17 с.

7. Чернявський С. С Злочини у сфері банківського кредитування (проблеми розслідування та попередження): [навч. посіб.] / Чернявский С. С.; за заг. ред.О. М. Джужи. - К.: Юрінком Інтер, 2003. -264 c.

8. Кодекс адміністративного судочинства України URL: https://zakon.rada.gov. ua/laws/show/2747-15.

9. Кощинець В.В. Спеціальне психологічне пізнання в юрисдикційному процесі: монографія / В.В.Кощинець; наук. ред. М.В.Костицький. - Київ:ФОП Маслаков, 2018. - 282 с.

10. Марчак В. Я. Використання спеціальних психологічних знань у досудовому слідстві: дис.... канд. юрид. наук : 12.00.09 / Марчак Віталій Ярославович. К., 2003. - 189 c. 
11. Костицький М. В. Психологічна консультація як форма використання спеціальних знань / М. В. Костицький // Науковий вісник УАВС. - К., 1997. - Вип. 1. - C 158-169.

12. Карпов Н. С. Криміналістичні засади вивчення злочинної діяльності : дис. ... доктора юрид. наук : 12.00.09 / Карпов Никифор Семенович. - Київ, 2008. - 827 с.

13. Про затвердження «Інструкції про призначення та проведення судових експертиз та Науково-методичних рекомендацій з питань підготовки та призначення судових експертиз та експертних досліджень : наказ Міністерства юстиції України від 08.10.1998 № 53/5. Офіційний вісник України. 1998. № 46. ст. 172.

\section{SUMMARY}

Modern administrative justice is aims at a fair, impartial and well - timed consideration and resolution of administrative cases with intended on effective protection of the violated, unrecognized or contested rights, freedoms or interests of individuals, rights and interests of legal entity, interests of the state. The use of special psychological knowledge or «special knowledge» in certain categories of administrative proceedings in the form of involvement of a consultant - psychologist and / or the appointment of forensic psychological examination will effectively contribute in general to solving the problems of administrative justice, outlined above and rstablished in Article 2 of the Code of Administrative Procedural of Ukraine. 